\title{
Weather conditions influencing phosphorus concentration in the growing period in the large shallow Lake Peipsi (Estonia/Russia)
}

\author{
Olga TAMMEORG,,$^{1,2 *}$ Tõnu MÖLS, ${ }^{1,3}$ Külli KANGUR ${ }^{1}$
}

${ }^{1}$ Centre for Limnology, Institute of Agricultural and Environmental Sciences, Estonian University of Life Sciences, Friedrich Reinhold Kreutzwaldi 1, 61117 Rannu, Estonia; ${ }^{2}$ Department of Environmental Sciences, University of Helsinki, P.O. Box 65, 00014 Helsinki, Finland; ${ }^{3}$ Department of Bioinformatics, Institute of Cell and Molecular Biology, University of Tartu, Riia 23, 51010 Tartu, Estonia *Corresponding author: olga.buhvestova@emu.ee

\begin{abstract}
The impact of water temperature (T), water level (L), photosynthetically active radiation (PAR), and wind speed (V) on the total phosphorus concentration (TP) in shallow eutrophic Lake Peipsi, the fourth largest lake in Europe, was studied. We used a long-term dataset (1985-2010) of TP concentrations and weather factors. A Thin Plate Spline (TPS) model was used to predict TP by year, by day of the year, and by geographical coordinates. Deviations between observed and predicted TP values (residuals, or TP anomalies) were related to the weather variables to clarify how the weather anomalies in a year might correlate with the observed fluctuations in TP dynamics. Notable seasonal variations in TP, typical for many shallow lake systems, were found: TP was two to three times higher during late summer-early autumn than during winter. Patterns of TP variability were well predicted by using geographical coordinates, year and day of the year $\left(\mathrm{R}^{2}=0.69 ; P<0.0001\right)$. However, TP anomalies were ascribed to the effects of $T, L, P A R$, and $V$, which were proved to play a significant additional role in TP dynamics. Moreover, L had consistently negative effects over the year, whereas the effects of T and PAR on TP change were seen to be dependent on the season. TP anomalies in Lake Peipsi were most sensitive to wind anomalies. $V$ was associated with frequent switches between increasing and decreasing TP values, though it appeared mainly as a negative driver of TP anomalies in the season prior to the $180^{\text {th }}$ day, and as a positive driver in the subsequent season.
\end{abstract}

Key words: large shallow lake, total phosphorus dynamics, water level, water temperature, photosynthetically active radiation, wind speed.

Received: March 2013. Accepted: September 2013.

\section{INTRODUCTION}

Phosphorus $(\mathrm{P})$ is recognised to play a central role in eutrophication and the determination of the structure and functioning of whole lake ecosystems (Istvánovics, 2008; Pettersson et al., 2010). Seasonal changes in P concentrations vary greatly from lake to lake. These variations can be attributed to the differences in the geochemistry of the areas, hydrology and mixing characteristics of the lakes, and supply of nutrients from different sources (Stewart and Markello, 1974). Generally, total phosphorus (TP) concentration has marked seasonality in many eutrophic shallow lakes, with concentrations in summer often being much higher than in winter due to the net release of this nutrient from sediments (Søndergaard et al., 1992, 2002; Spears et al., 2008; Lagomarsino et al., 2011).

The levels of TP in lakes are associated with seasons and influenced by weather conditions, which may obscure or exaggerate eutrophication processes. Light providing the energy required for algal growth can be a major driver of the seasonality in seston and its $\mathrm{P}$ content (Lagomarsino et al., 2011). Water temperature is commonly understood to control all processes in a lake including the release of $\mathrm{P}$ from sediments through elevated microbial remineralisation, the onset of anoxia, and increased diffusion rates (Spears et al., 2007). However, the effect of water level on nutrient concentrations has been rather controversial. Decreases in water level make the sediments more prone to resuspension, which results in increases in nutrient concentrations and in decreases in water clarity (Kristensen et al., 1992; Nagid et al., 2001; Nõges et al., 2003). Nevertheless, some lakes have manifested no changes in TP in response to changes in water level (Hoyer et al., 2005; Garrison et al., 2010). Wind has been identified as the main driving force behind $\mathrm{P}$ dynamics at different (hourly, daily, and seasonal) time scales (Havens et al., 2007).

Given the projected changes in climate (IPCC, 2007), studies on the responses of lake ecosystems to weather factors are now of particular relevance (Jennings et al., 2012). Despite being fragmentary, long-term monitoring records of the large shallow body of water that forms Lake Peipsi have been of great importance for understanding those factors affecting the functioning of that lake's ecosystem (Haldna et al., 2008; Kangur and Möls, 2008; Haldna et al., 2013; Kangur et al., 2013). In the present study, we applied advanced statistical methods for 
analysing the long-term series of TP to ascertain the roles of water temperature (T), water level (L), mean and maximal wind speed (V, Vmax), and photosynthetically active radiation (PAR) in causing TP anomalies appearing as deviations between observed and predicted TP concentrations. Our approach was based on the null hypothesis that the variability of TP can be explained purely by the longterm trend over years, the seasonal time, and the geographical coordinates. The falsification of this hypothesis indicates that the studied weather factors play a significant additional role in TP dynamics. Moreover, the applied statistical methods enabled us to estimate explicitly the role of each of the weather factors in modifying the TP dynamics. This is one of the first studies, whereby the sensitivity of TP anomalies to the studied weather factors is quantitatively estimated.

\section{METHODS}

\section{Study area}

Located on the border between Estonia and Russia, Lake Peipsi is the largest transboundary lake in Europe (Fig. 1). The surface area of the lake is $3555 \mathrm{~km}^{2}$ at the mean water level of $30 \mathrm{~m}$ asl, and the water residence time is approximately two years. The lake, where thermal stratification is episodic and unstable, is classified as belonging to the polymictic type of lakes. The waters of Lake Peipsi are usually rich in oxygen during the ice-free period (April to November).

The three parts of Lake Peipsi have different mor- phometry, hydrology, trophic states, and composition of biota (Kangur et al., 2003). The northern part, Lake Peipsi sensu stricto (s.s.) is the largest $\left(2611 \mathrm{~km}^{2}\right)$ and has the greatest mean depth $(8.3 \mathrm{~m})$. The southern parts of the lake continuum, i.e. Lakes Lämmijärv and Pihkva, are considerably smaller and shallower than the northern part (Lake Lämmijärv: $236 \mathrm{~km}^{2}$, mean depth $2.6 \mathrm{~m}$; Lake Pihkva: $708 \mathrm{~km}^{2}$, mean depth $3.8 \mathrm{~m}$ ). According to the Organisation for Economic Co-operation and Development (OECD) classification of 1982, the existing conditions characterise Lake Peipsi s.s. as an eutrophic waterbody, whereas the trophic status of Lake Lämmijärv makes it close to hypertrophic and Lake Pihkva is classified as a hypertrophic basin (Kangur et al., 2013). Most of the nutrients are carried into the lake by Rivers Velikaya and Emajõgi: their catchment areas $(25,200$ and $9740 \mathrm{~km}^{2}$ ) cover almost $80 \%$ of the total drainage basin of Lake Peipsi (Loigu et al., 2008).

Drastic changes occurred in the catchment area of Lake Peipsi over the 1985-2010 period. These changes included lower water consumption by people and industries, improved wastewater treatment and lower intensity of agriculture (Iital et al., 2005, 2010). As a result, nitrogen loading and to a lesser extent $\mathrm{P}$ loading from the Estonian part of the catchment to Lake Peipsi decreased in the 1990s (-39 and -13\%, respectively; Nõges et al., 2007). Despite the decline in agricultural activity in the late 1980s and early 1990s, agriculture still causes much of the diffuse pollution of inland surface waters [ $62 \%$ of total nitrogen (TN) and 43\% of TP loading; Loigu et al., 2008;

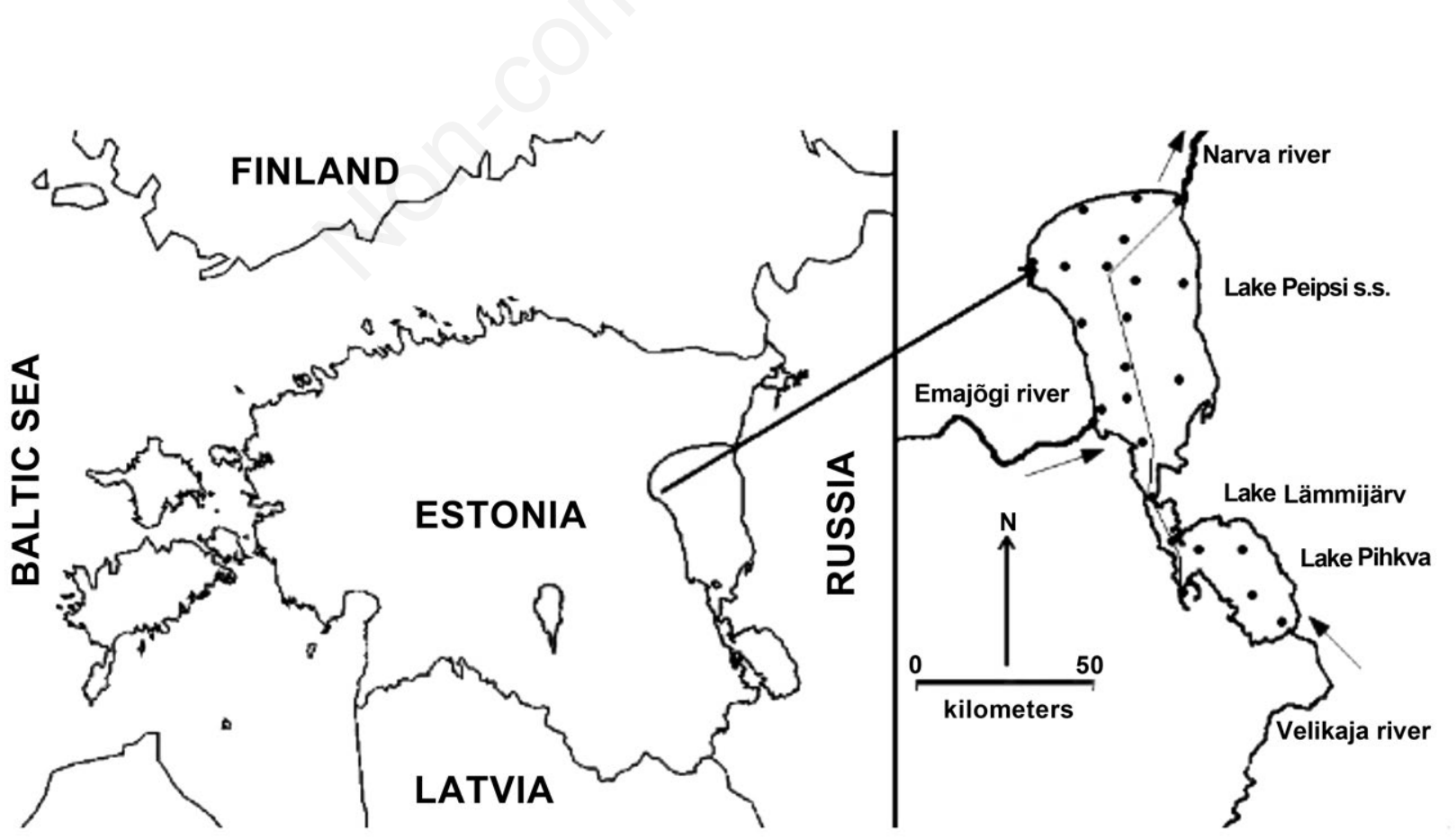

Fig. 1. Location of Lake Peipsi, its three parts, and sampling sites (dots). 
Iital et al., 2010]. Maximum nutrient inflow to Lake Peipsi occurs usually during the snowmelt in early spring (Rumyantsev et al., 2005).

\section{Sampling strategy}

Water samples for nutrient analysis were collected monthly, predominantly in the ice-free period (from AprilMay to October-November) of 1985-2010. During the study period, the number of the sampling sites varied noticeably. However, most of the data since 1992 have been collected from six stations in the pelagic zone of the Estonian side of Lake Peipsi, by Tartu Environmental Researches Ltd. (Tartu, Estonia). In the 1980s, samples were collected and analysed for TP concentrations at the Institute of Zoology and Botany in Tartu. Since 2001 joint Estonian - Russian expeditions on the whole lake have been conducted generally twice a year, in March and in August. Seasonal (monthly) water samples for TP analysis have been obtained from the surface layer $(0.1-1.0 \mathrm{~m})$ and TP has been determined in the water samples by the ammonium molybdate spectrometric method (EVS-ES 1189).

Mean daily values of $\mathrm{L}, \mathrm{T}, \mathrm{V}, \mathrm{V} \max$, and PAR for the years 1980-2010 were obtained from the Institute of Meteorology and Hydrology of the Estonian Ministry of the Environment. Water level, T, V, and Vmax measurements were made at the Mustvee hydrometric station of Lake Peipsi $\left(58^{\circ} 50^{\prime} \mathrm{N}, 2^{\circ} 57^{\prime} \mathrm{E}\right)$. Photosynthetically active radiation was measured at the Torravere observatory (at ground level) located at a distance of $50 \mathrm{~km}$ from the western shore of Lake Peipsi. Weather data that were measured at Mustvee and Tõravere observatory were assumed to be characteristic of the entire lake in the present study.

\section{Statistical analysis}

Total phosphorus values were transformed using $\log _{2}$ to logarithmic TP (LTP). Unlike the TP, the LTP has a residual distribution similar to a normal distribution, which is needed for correct statistical inferences.

We initially separated the part related to the sampling time and site from the general variability of LTP. These factors are fixed by the study design and do not depend on weather factors although they are correlated with them. Consequently, the sampling time and site were considered as static factors. We predicted the LTP value for a site on a given day of a year by using the Thin Plate Splines (TPS) interpolation technique provided by the SAS TPS procedure (SAS, 2008). Thin Plate Spline are smooth functions that allow one to predict LTP value for arbitrary time and site on the basis of real measurements, irrespective of whether these coincide with the conditions of the real observations or not. The TPS procedure allows great flexibility thus enabling one to choose an appropriate model by specifying the degrees of freedom and several smoothing parameters. We used 266 degrees of freedom for the spline model, which is about $14 \%$ of the $1862 \mathrm{TP}$ observations used: this value was also recommended by SAS statistical algorithms as the best one for optimal model rigidity.

The deviations of observed LTP values from the corresponding predicted ones are hereafter called the residuals, or TP anomalies. Residuals here can be considered as LTP measurements that have been subjected to an elimination of the effects attributed to various smooth and regular changes in the lake (external loading, climatic change, changes in biota, seasonal periodic changes, etc.), and also attributed to the geographical differences between the sampling sites. It is noteworthy that weather conditions were also indirectly considered in the TPS model, but only to the extent that they determined the consistency over the years for a given area (for example, usual seasonal changes in TP that are determined by usual seasonal changes in weather variables). Consequently, the residuals would no longer be dependent on the factors listed, but they would still continue to depend on weather factors such as L, T, PAR, and $\mathrm{V}$, which vary too randomly and fast to be taken fully into account in the TPS modelling. Hence, we tested the possible effects of these latter weather factors on the residuals. If a significant effect could be established, then it would reveal that the TP depends not only on the static factors, but also on the weather factors. Moreover, numerical estimations of weather factor effects can help to clarify how the weather anomalies of a year correlate with the observed peculiarities of LTP dynamics and seasonality.

Effects of the weather factors were estimated by using the SAS GLM procedure for predicting the LTP residuals, in a model containing all the weather factors and their second-order products. The effect of a weather factor represents the sensitivity of TP anomalies to that weather factor as well. This appeared as the predicted percentage change of the TP, when the factor in question was increased by one unit from its mean value while the other factors were kept constant at their mean values. Technically, the effects were determined by the estimate command of the GLM procedure. Further, the effect of each factor was multiplied by the standard deviation of the factor in the period under study. This standardisation of the factors enabled the removal of the scale effects and allowed the comparison of the sensitivity of TP anomalies to different factors.

The influence of weather factors may be non-linear and delayed. Additionally, the means of factor values in a group of several adjacent days may be statistically more influential predictors than the factor value for any single day. Thus, we also considered to calculate the means of factors over periods of up to 6 subsequent days and backward time shifts of 0 to 7 days with respect to the sampling day. Days before sampling, including the actual sampling day, over which a factor was averaged, were 
called effect days, if the effect of a corresponding mean was statistically different from zero. As a result, 48 separate analyses were run, differing in the way the factors were averaged. In this part of analysis, we considered only days of temperature over $12^{\circ} \mathrm{C}$, and analysed them in three groups: all the days, days before and after the $180^{\text {th }}$ Julian day. Therefore, for the final analysis, the total data set included only 1175 TP measurements (of 1862 real TP measurements) for the years 1985-2010. The $180^{\text {th }}$ Julian day was used as a boundary between two periods (days from 110 to 180 , and 180 to 300) previously described for major changes in TP (Haldna et al., 2008).

Generally, the seasons (spring: from 110 to 180 days; summer: from 180 to 240 days; autumn: from 240 to 300 days; and winter: the remaining days of the year) were used to describe variations in weather conditions. The seasonal characteristics of Lake Peipsi were previously described by Jaani (2001).

\section{RESULTS}

\section{Weather conditions over the $1980-2010$ period}

Lake Peipsi experienced notable changes in the L (values are given in $\mathrm{cm}$ above $28 \mathrm{~m}$ asl) over the 30 -year period of recording (Fig. 2). Moreover, the L has shown high levels of annual variability: values have fluctuated between 110 and $306 \mathrm{~cm}$ (mean value $190 \mathrm{~cm}$ ) in winter, and between 108 and $297 \mathrm{~cm}$ (mean value $182 \mathrm{~cm}$ ) in autumn. There was a tendency for the highest $\mathrm{L}$ values to occur during springtime (mean value $230 \mathrm{~cm}$ ). During summer, the L usually decreased at a steady rate, resulting in a mean value of $204 \mathrm{~cm}$. When the growing season was divided into two periods with respect to the $180^{\text {th }}$ Julian day, the corresponding mean values ( \pm standard deviation) were $229 \pm 35$ and $198 \pm 34 \mathrm{~cm}$.

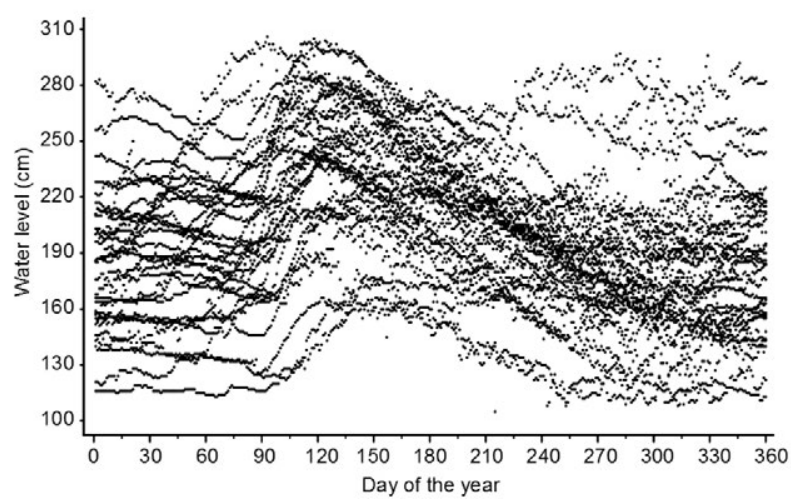

Fig. 2. Mean daily water levels (in $\mathrm{cm}$ above $28 \mathrm{~m}$ asl) in Lake Peipsi sensu stricto during the $1980-2010$ period according to the Mustvee hydrometric station.
Photosynthetically active radiation also varied greatly during the same period (5 and $95 \%$ quartiles in spring: 2.5 and $12.3 \mathrm{MJ} \mathrm{m}^{-2}$; in summer: 2.7 and $11.8 \mathrm{MJ} \mathrm{m}^{-2}$ ). The seasonal patterns of the $\mathrm{T}$ were, in essence, linked to the PAR levels, although the $T$ induced changes occurred after a delay of about 20 days as changes to the PAR values. Nevertheless, changes in T (Fig. 3b) were notably smoother than changes in PAR (Fig. 3a). The annual T displayed a marked seasonality, with the highest values $\left(28.8^{\circ} \mathrm{C}\right)$ in late spring-early summer and the lowest values in winter, when the temperature was seen to drop to zero (Fig. 3b). Mean values of PAR and T were 8.6 \pm 2.9 $\mathrm{MJ} \mathrm{m}{ }^{-2}$ and $16.8 \pm 3.1^{\circ} \mathrm{C}$ in the period prior to the $180^{\text {th }}$ day (days from 110 to 180). In the subsequent period (days from 180 to 300 ), the PAR and T mean values were $6.4 \pm 3$ $\mathrm{MJ} \mathrm{m}^{-2}$ and $18.7 \pm 3.6^{\circ} \mathrm{C}$.

No seasonal pattern in the $\mathrm{V}$ values became apparent (not shown). The mean daily value for the whole study period was $2.7 \mathrm{~m} \mathrm{~s}^{-1}$. In the years 1980-2010, the maximum daily $\mathrm{V}$ varied between 0.0 and $18.0 \mathrm{~m} \mathrm{~s}^{-1}$. Moreover, a maximum Vmax exceeding $10 \mathrm{~m} \mathrm{~s}^{-1}$ was recorded in every month in the study period. Mean values of $\mathrm{V}$ and Vmax were $2.5 \pm 0.9$ and $4.1 \pm 1.5 \mathrm{~m} \mathrm{~s}^{-1}$ in the period prior
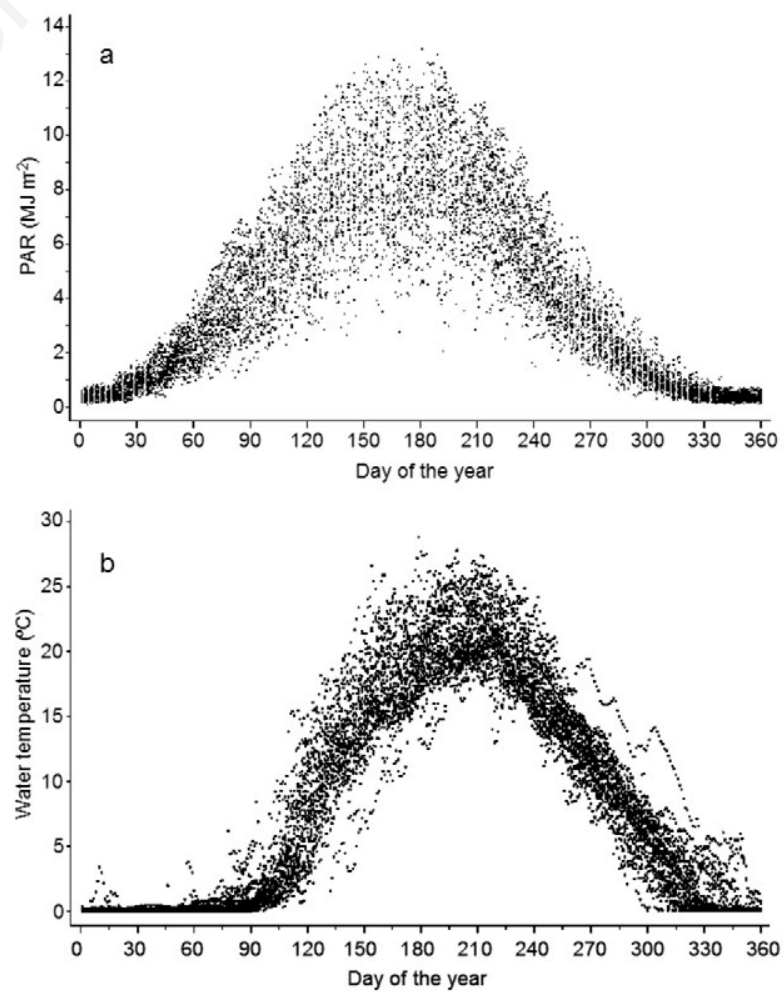

Fig. 3. Mean daily photosynthetically active radiation measured at a distance of $50 \mathrm{~km}$ from the western shore of Lake Peipsi at ground level (a) and mean daily water temperatures in Lake Peipsi sensu stricto (b) during the 1980-2010 period. 
to the $180^{\text {th }}$ day. In the subsequent period, the $\mathrm{V}$ and $\mathrm{Vmax}$ mean values were $2.4 \pm 1$ and $3.9 \pm 1.6 \mathrm{~m} \mathrm{~s}^{-1}$.

\section{Seasonal variations in total phosphorus concentration}

The TP values were highest during late summer-early autumn and lowest during the winter-spring periods in Lake Peipsi (see the seasonal distribution of measured TP in Fig. 4 and predicted TP values in Fig. 5). This general seasonal pattern was more pronounced in the smaller and shallower Lake Lämmijärv (Figs. 4 and 5a) than in the larger and deeper Lake Peipsi s.s. (Figs. 4 and 5b). Moreover, the peak of TP was reached earlier in Lake Lämmijärv compared to Lake Peipsi s.s., and it peaked at higher levels during late summer-early autumn in Lake Lämmijärv than it did in Lake Peipsi s.s. However, the TP varied noticeably over the study period (Fig. 6), particularly for the summer-autumn season (Figs. 4 and 5). In AugustSeptember, $90 \%$ of TP measurements varied between 50 and $150 \mathrm{mg} \mathrm{P} \mathrm{m}^{-3}$ for Lake Lämmijärv, and between 20 and $80 \mathrm{mg} \mathrm{P} \mathrm{m}^{-3}$ for Lake Peipsi s.s (Fig. 4). Moreover, the annual maximum TP (in late summer-early autumn) correlated well with the mean annual TP in Lake Peipsi (Lake Peipsi s.s.: $R^{2}=0.69, \mathrm{P}<0.001$; Lake Lämmijärv: $\left.R^{2}=0.75, \mathrm{P}<0.001\right)$. Mean annual TP in Lake Peipsi s.s was lowest in 1990 (25 $\mathrm{mg} \mathrm{P} \mathrm{m}^{-3}$; Fig. 6). Then it peaked at $54 \mathrm{mg} \mathrm{P} \mathrm{m}^{-3}$ in 1992. In general, there was a steadily declining trend $\left(R^{2}=0.51, \mathrm{P}<0.001\right)$ in the mean annual TP since 1992 for Lake Peipsi s.s. In Lake Lämmijärv, mean annual TP values underwent noticeably larger fluctuations, without any clear trends.

\section{Factors behind total phosphorus variation}

With the aid of the TPS model, we found that TP can be predicted rather well by geographical coordinates, year and day of the year $\left(R^{2}=0.69, \mathrm{P}<0.0001\right.$; Fig. 7). Further-

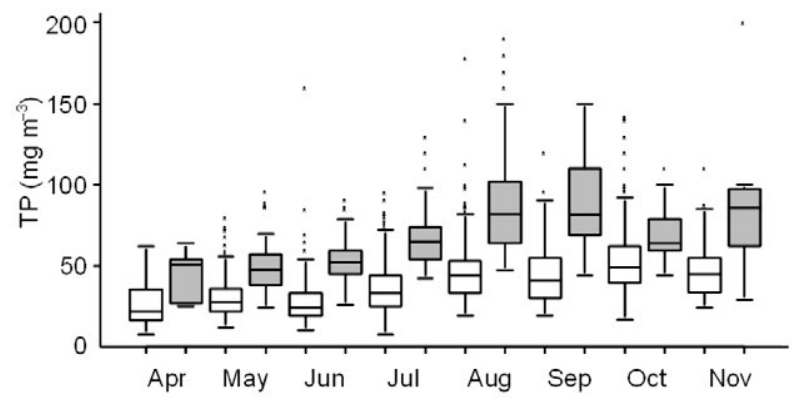

Fig. 4. Seasonal changes in total phosphorus concentrations measured in Lake Peipsi sensu stricto (white box) and Lake Lämmijärv (grey box) over the 1985-2010 period. Data are presented in box plots showing median, quartiles, 5 and 95\% percentiles, outliers (asterisks) for each month of the study period. more, we established statistically significant influences of T, L, PAR, and V on the LPT residuals, which remained after elimination of the effects of the static factors (Tab. 1). Increases in L relative to what was expected for the specific year, the day of the year and sampling site resulted in a decrease of TP, regardless of whether the period before or after the $180^{\text {th }}$ Julian day was considered. The estimated decreases in TP were about $0.14 \%$ when $\mathrm{L}$ increased by one unit $(\mathrm{cm})$ from its mean value (given that the other factors were kept at their mean values). The effects of increases or decreases of T or PAR on TP were found to depend on the season. However, TP values appeared to be most sensitive to the anomalies in wind speed. After standardisation, the effect of the wind speed factor (Tab. 1) appeared to be of
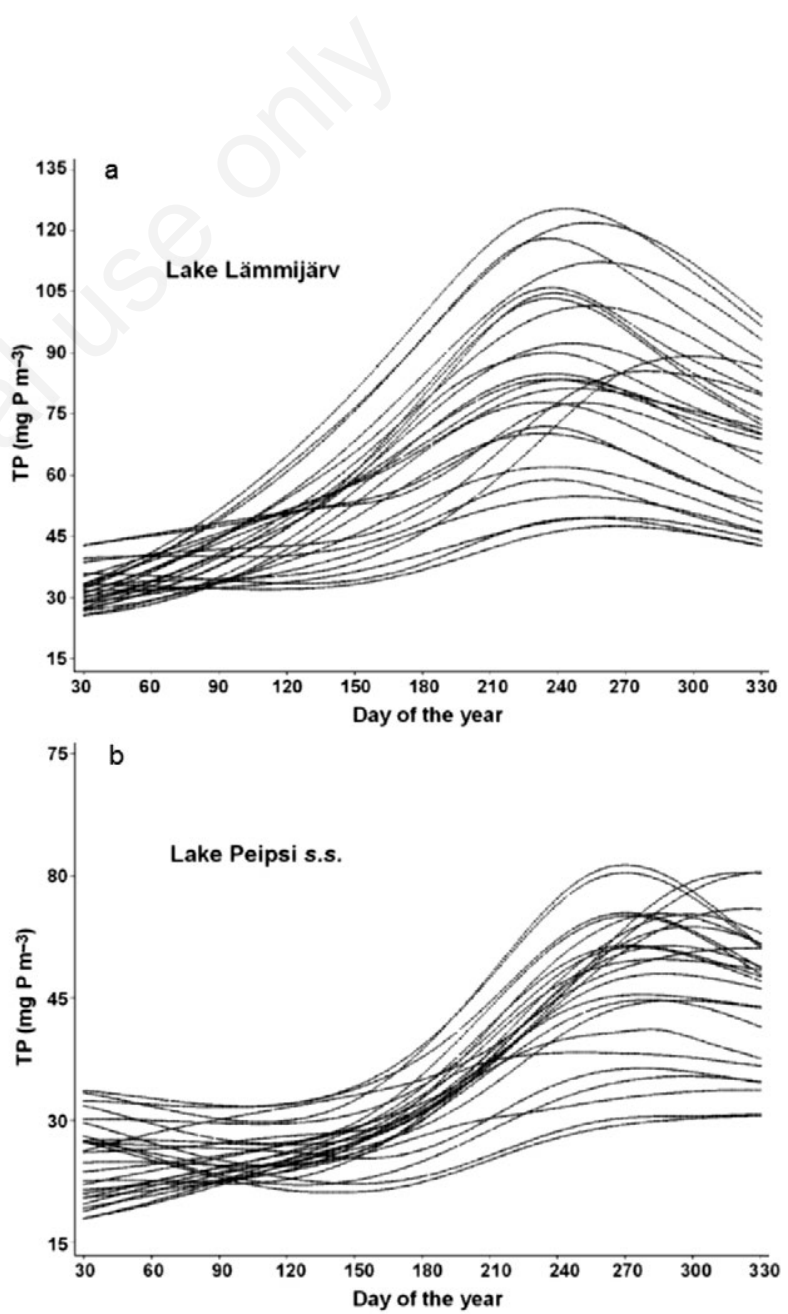

Fig. 5. Seasonal patterns in predicted mean total phosphorus (TP) concentration in Lake Lämmijärv (a) and Lake Peipsi sensu stricto (b) for the 1985-2010 period. Lines correspond to cross-sections of the four-dimensional spline surface fitted to TP by using the year, day within the year, and the two geographical co-ordinates as smoothing factors. Each line shows the surface section for a fixed year; lines in a) are generated by sections through the geographical point $58^{\circ} 23^{\prime} \mathrm{N}, 27^{\circ} 42^{\prime} \mathrm{E}$, while those in b) run through point $58^{\circ} 80^{\prime} \mathrm{N}, 27^{\circ} 36^{\prime} \mathrm{E}$. 
highest magnitude (before the $180^{\text {th }}$ day: $-30.6 \%$; after the $180^{\text {th }}$ day: $32.1 \%$ ), and it was three-fold of those TP value changes attributed to temperature. Fluctuating $\mathrm{V}$ and $\mathrm{V} \max$ were associated with frequent switches between positive and negative influences. Nevertheless, our analysis resolved the switch of the mean effect of $\mathrm{V}$ from strongly negative in the period prior to $180^{\text {th }}$ Julian day to strongly positive for the period after $180^{\text {th }}$ Julian day.

\section{DISCUSSION}

Lake Peipsi is similar to many shallow lakes, whereby internal loading tends to be the principal component of $\mathrm{P}$ supply for phytoplankton in summer when external nutrient loading is low: a trough of the hydrograph has been reported at this time of the year (Jaani, 2001; Starast et al., 2001). It has been widely accepted that internal P loading delays the recovery of shallow lakes from eutrophi-

Tab. 1. Significant effects of weather factors on total phosphorus concentration.

\begin{tabular}{|c|c|c|c|c|c|}
\hline Weather factor & Effect days & Effect count & Mean effect $(\%)$ & Min effect $(\%)$ & Max effect $(\%)$ \\
\hline \multicolumn{6}{|l|}{ All days (1175 TP observations) } \\
\hline Water temperature $\left({ }^{\circ} \mathrm{C}\right)$ & $4-8$ & 5 & 1.31 & 1.04 & 1.58 \\
\hline Water level $(\mathrm{cm})$ & $0-12$ & 46 & -0.14 & -0.20 & -0.10 \\
\hline Photosynthetically active radiation $\left(\mathrm{MJ} \mathrm{m}^{-2}\right)$ & $0-9$ & 31 & -1.98 & -2.73 & -1.30 \\
\hline Wind speed (mean) $\left(\mathrm{m} \mathrm{s}^{-1}\right)$ & $1-12$ & 8 & -19.5 & -52.2 & 35.2 \\
\hline Wind speed $(\max )\left(\mathrm{m} \mathrm{s}^{-1}\right)$ & $3-6$ & 4 & -8.03 & -16.7 & 4.61 \\
\hline \multicolumn{6}{|c|}{ Days before the $180^{\text {th }}$ Julian day (479 TP observations) } \\
\hline Water temperature $\left({ }^{\circ} \mathrm{C}\right)$ & $0-8$ & 19 & -3.17 & -5.22 & -1.99 \\
\hline Water level $(\mathrm{cm})$ & $0-10$ & 16 & -0.28 & -0.35 & -0.20 \\
\hline Photosynthetically active radiation $\left(\mathrm{MJ} \mathrm{m}^{-2}\right)$ & $0-12$ & 6 & 0.47 & -6.74 & 4.79 \\
\hline Wind speed (mean) $\left(\mathrm{m} \mathrm{s}^{-1}\right)$ & $2-12$ & 10 & -32.2 & -87.0 & 121 \\
\hline \multicolumn{6}{|c|}{ Days after the $180^{\text {th }}$ Julian day (703 TP observations) } \\
\hline Water temperature $\left({ }^{\circ} \mathrm{C}\right)$ & $0-8$ & 8 & 2.48 & 1.95 & 2.99 \\
\hline Water level $(\mathrm{cm})$ & $2-5$ & 4 & -0.15 & -0.17 & -0.13 \\
\hline Photosynthetically active radiation $\left(\mathrm{MJ} \mathrm{m}^{-2}\right)$ & $0-9$ & 25 & -3.46 & -5.49 & -2.22 \\
\hline Wind speed (mean) $\left(\mathrm{m} \mathrm{s}^{-1}\right)$ & $7-7$ & 1 & 31.1 & 31.1 & 31.1 \\
\hline Wind speed $(\max )\left(\mathrm{m} \mathrm{s}^{-1}\right)$ & $1-5$ & 3 & -18.3 & -23.6 & -8.55 \\
\hline
\end{tabular}

$\overline{T P \text {, total phosphorus concentration. The residuals were calculated by subtracting the logarithmic total phosphorus concentration (LTP) value predicted }}$ by spline technique from the observed LTP by using the long-time trend, seasonal dynamics and geographical coordinates as predictors. We used to average over 1 to 6 days, for 0 to 7 days before the TP sampling. Analyses revealing significant $(P<0.001)$ factor effects are called positive and their number is called effects count. For positive analyses the minimal, maximal and mean factor effects are given.

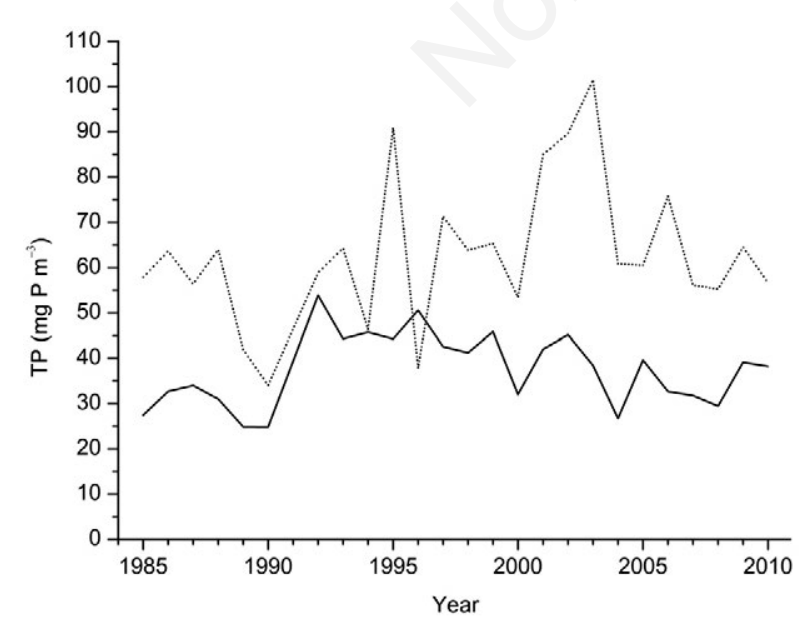

Fig. 6. Mean annual phosphorus concentrations for Lake Peipsi sensu stricto (solid line) and Lake Lämmijärv (dashed line) measured in the growing season (Julian days 100-310 within each year) during the study period (1985-2010).

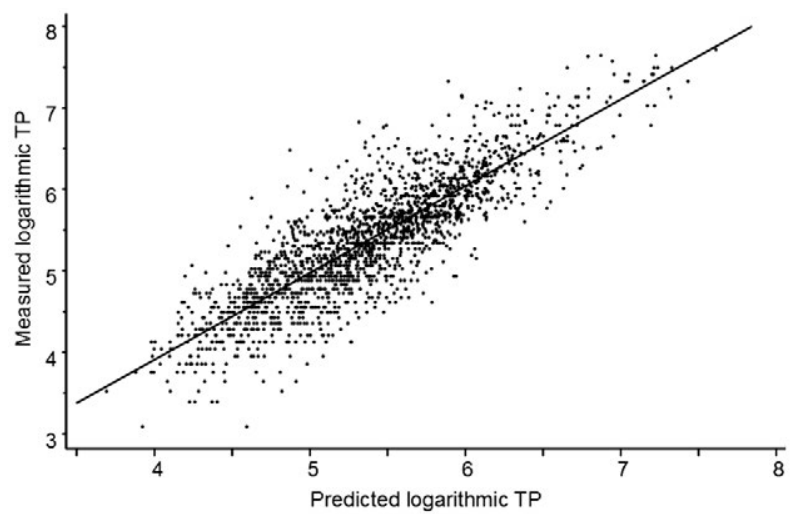

Fig. 7. Relationship between measured and predicted (from year, day of the year and geographical coordinates) logarithmic total phosphorus concentration $[\log 2(\mathrm{TP})]$ in Lake Peipsi. 
cation (Søndergaard et al., 2002; Jeppesen et al., 2005; Spears et al., 2012). However, slow decline in internal $\mathrm{P}$ loading has been reported after the reduction in loading for a number of lakes (Søndergaard et al., 2002, 2013; Spears et al., 2012). Similar changes, i.e. a sharp increase, followed by a steady decline, have been observed in annual mean and maximum TP in Lake Peipsi s.s., which experienced drastic changes in the supply of nutrients in the late 1980s and early 1990s (Loigu et al., 2008). In addition to the high internal loading, the current high TP levels compared to those of the 1980s have been associated with unchanged external loading from the Russian part of the catchment area to climate change and to changes in the biotic structure (Nõges et al., 2007; Buhvestova et al., 2011). The importance of lake morphology in terms of changes in water quality has also been demonstrated by the modelling results (Janse et al., 2008). Owing to smaller depth, size, and in addition to higher TP values in the water, Lake Lämmijärv appears to be more sensitive than Lake Peipsi s.s. to the disturbances, as was indicated by a more pronounced seasonal pattern, higher fluctuations in annual mean TP (Fig. 6), higher variation of summer TP (Figs. 4 and 5a). This is in accordance with the conclusion made by Søndergaard et al. (2013), who reported more pronounced seasonal variations in $\mathrm{P}$ retention with increasing $\mathrm{P}$ levels. These various smooth and regular changes in the lake TP mentioned above can be rather well predicted by geographical coordinates, year and day of the year (Fig. 7).

The present study has found an effect of weather factors on P variability, additional to those that have been already captured by fitting a seasonal dynamics to the data. Since temperature controls the rate of almost all processes in the lake, it has been generally suggested to act as a major integrating factor for a number of influences (Søndergaard, 2007). According to the results of the present study, no other factor had the magnitude of effect on TP that was attributed to wind. The result confirms the conclusion made previously by Spears and Jones (2010), who suggested that wind effects might supersede the temperature effects in large shallow lakes with high fetch.

The mechanisms behind the influences, leading to fluctuations in TP, are less easily explained. Changes in the summer levels of TP (after 180 ${ }^{\text {th }}$ day) in Lake Peipsi are probably associated with weather variables through the effect on internal release of P. Higher temperatures lead to an increased release of nutrients from the sediments into the water column (Pettersson et al., 2003; Spears et al., 2007). On the other hand, lower water levels can also be associated to an increased probability of sediment disturbance due to sediment resuspension (Kristensen et al., 1992; Nagid et al., 2001; Nõges et al., 2003). The synergistic effects of $\mathrm{L}$ and $\mathrm{T}$ on water quality in Lake
Peipsi, i.e. increases in TP during periods with lower L and higher $\mathrm{T}$ (for the 2000-2003 period compared to the 1985-1988 period), have been well documented (Haldna et al., 2008).

However, warmer spring temperatures have been suggested to have a positive effect on Daphnia densities and cause reduced chlorophyll $a$ concentrations in spring (in May and June) in loch Leven in Scotland, where phytoplankton contributes significantly to the overall budget of TP (Carvalho et al., 2012). Similar mechanisms could be responsible for the negative effects of higher spring water temperatures on TP in Lake Peipsi, where the biomass of cladocerans has been found to correlate positively with the sum of daily water temperatures in spring (April, May, June over the 1997-2007 period; Blank et al., 2009). It is likely that PAR in the period after $180^{\text {th }}$ day was associated with decreasing TP values via the compounding influences from other factors. In general, the correlations between PAR and phytoplankton in previous studies on Lake Peipsi revealed changing annual relationships (both positive and negative; Laugaste et al., 2001). Thus, our results confirm the conclusion of Carvalho et al. (2012), who showed that seasonal changes in weather conditions can have both positive and negative impacts on water quality.

The TP anomalies were found to be the most sensitive to the anomalies in wind speed. Wind has been demonstrated to impact sediment-water interactions, particularly in large shallow lakes (Bachmann et al., 2000; Havens et al., 2007; Kelderman et al., 2012; Spears et al., 2012). Wind-induced resuspension mixes P-rich sediment particles and interstitial $\mathrm{P}$ into the water column, and this transport at any given time can be orders of magnitude greater than other inputs of $\mathrm{P}$ such as by diffusion and external loading (Havens et al., 2007; Niemistö et al., 2012).

In a recent study on sediment resuspension in large shallow waters of Lake Peipsi, wind was identified to be the main driving force behind the variations in sediment resuspension (Tammeorg et al., 2013). The effect of wind was found to be particularly pronounced at lower water levels in September, when the highest rates of sediment resuspension, and when the highest concentrations of suspended solids, TP, and Chl $a$ were measured. Moreover, higher water levels in May reduced the ability of wind to disturb sediment surface. Thus, the results of the present study, which revealed a mainly increasing effect of wind on TP values in a period after the $180^{\text {th }}$ Julian day, and reducing influences in the preceding period, are in close agreement with the results obtained from a sediment-trap field survey (Tammeorg et al., 2013). Therefore, the results of the present study suggest severe implications of climate change on the lake ecosystems such as an increase of internal phosphorus loading, since a higher frequency of extreme wind events can be expected in the future (Jeppesen et al., 2009). 


\section{CONCLUSIONS}

It is a complex task to identify all the factors that determine TP in large shallow lakes because the $\mathrm{P}$ cycle is influenced by multiple processes. The factors affecting $\mathrm{P}$ dynamics are generally interrelated, and these interactions confound attempts to separate one specific effect, e.g. that due to weather variables. Long-term datasets for Lake Peipsi, together with advanced statistical methods, have enabled us to reveal the contribution of weather factors including L, T, PAR, and V to the variability in P concentrations. Some variability of $\mathrm{P}$ remains after statistical removal of the effects of those factors (i.e. geographical coordinates, year and seasonality) that determine consistency over long time-scales. Highly episodic wind events were identified to be the main drivers behind TP anomalies. This suggests severe implication of climate change for the quality of the lake water.

\section{ACKNOWLEDGMENTS}

The study was supported by the Estonian Ministry of Education and Research (target-financed projects SF0170006s08, SF0180026s09 and the ESF grants No. 7643 and 7392). We acknowledge Prof. Jukka Horppila, Priit Tammeorg and Marina Haldna for their generous advice. We thank Dr. Renee Miller (UK) and one anonymous reviewer for language editing.

\section{REFERENCES}

Bachmann RW, Hoyer MV, Canfield DE, 2000. The potential for wave disturbance in shallow Florida lakes. Lake Reserv. Manage. 16:281-291.

Blank K, Haberman J, Haldna M, Laugaste R, 2009. Effect of winter conditions on spring nutrient concentrations and plankton in a large shallow Lake Peipsi (Estonia/Russia). Aquat. Ecol. 43:745-753.

Buhvestova O, Kangur K, Haldna M, Möls T, 2011. Nitrogen and phosphorus in Estonian rivers discharging to Lake Peipsi: estimation of loads and seasonal and spatial distribution of concentrations. Est. J. Ecol. 60:18-38.

Carvalho L, Miller C, Spears BM, Gunn IDM, Bennion H, Kirika A, May L, 2012. Water quality of Loch Leven: responses to enrichment, restoration and climate change. Hydrobiologia 681:35-47.

Garrison PJ, Laliberte GD, Ewart BP, 2010. The importance of water level changes and shoreline development in the eutrophication of a shallow, seepage lake. P. Acad. Nat. Sci. Phila. 160:113-126.

Haldna M, Milius A, Laugaste R, Kangur K, 2008. Nutrients and phytoplankton in Lake Peipsi during two periods that differed in water level and temperature. Hydrobiologia 599:3-11.

Haldna M, Möls T, Buhvestova O, Kangur K, 2013. Predictive model for phosphorus in large shallow Lake Peipsi: approach based on covariance structures. Aquat. Ecosyst. Health 16:222-226.

Havens KE, Jin KR, Iricanin N, James RT, 2007. Phosphorus dy- namics at multiple time scales in the pelagic zone of a large shallow lake in Florida, USA. Hydrobiologia 581:25-42.

Hoyer MV, Horsburgh CA, Canfield DE, Bachmann RW, 2005. Lake level and trophic state variables among a population of shallow Florida lakes and within individual lakes. Can. J. Fish. Aquat. Sci. 62:2760-2769.

Iital A, Pachel K, Loigu E, Pihlak M, Leisk Ü, 2010. Recent trends in nutrient concentrations in Estonian rivers as a response to large-scale changes in land-use intensity and lifestyles. J. Environ. Monitor. 12:178-188.

Iital A, Stålnacke P, Deelstra J, Loigu E, Pihlak M, 2005. Effects of large-scale changes in emissions on nutrient concentrations in Estonian rivers in the Lake Peipsi drainage basin. J. Hydrol. 304:261-273.

IPCC, 2007. Summary of policymakers, p. 7-22. In: M.L. Parry, O.F. Canziani, J.P. Palutikof, P.J. van der Linden and C.E. Hanson (eds.), Climate change 2007: impacts, adaptation and vulnerability. Contribution of working group II to the Fourth assessment report of the Intergovernmental Panel on Climate Change. Cambridge University Press.

Istvánovics V, 2008. The role of biota in shaping the phosphorus cycle in lakes. Freshw. Rev. 1:143-174.

Jaani A, 2001. The location, size and general characterisation of Lake Peipsi and its catchment area, p. 10-17. In: T. Nõges (ed.), Lake Peipsi: meteorology, hydrology, hydrochemistry. Sulemees Publ.

Janse JH, De Senerpont Domis LN, Scheffer M, Lijklema L, Van Liere L, Klinge M, Mooij WM, 2008. Critical phosphorus loading of different types of shallow lakes and the consequences for management estimated with the ecosystem model PCLake. Limnologica 38:203-219.

Jennings E, Jones S, Arvola L, Staehr PA, Gaiser E, Jones ID, Weathers KC, Weyhenmeyer GA, Chiu CY, Eyto ED, 2012. Effects of weather-related episodic events in lakes: an analysis based on high-frequency data. Freshwater Biol. 57:589-601.

Jeppesen E, Kronvang B, Meerhoff M, Sondergaard M, Hansen KM, Andersen HE, 2009. Climate change effects on run off, catchment phosphorus loading and lake ecological state, and potential adaptations. J. Environ. Qual. 38:1930-1941.

Jeppesen E, Søndergaard M, Jensen JP, Havens KE, Anneville O, Carvalho L, Coveney MF, Deneke R, Dokulil MT, Foy B, Gerdeaux D, Hampton SE, Hilt S, Kangur K, Köhler J, Lammens EHHR, Lauridsen TL, Manca M, Miracle MR, Moss B, Nõges P, Persson G, Phillips G, Portielje R, Romo S, Schelske CL, Straile D, Tatrai I, Willén E, Winder M, 2005. Lake responses to reduced nutrient loading: an analysis of contemporary long-term data from 35 case studies. Freshwater Biol. 50:1747-1771.

Kangur K, Kangur P, Ginter K, Orru K, Haldna M, Möls T, Kangur A, 2013. Long-term effects of extreme weather events and eutrophication on the fish community of shallow Lake Peipsi (Estonia/Russia). J. Limnol. 72:376-387.

Kangur K, Möls T, 2008. Changes in spatial distribution of phosphorus and nitrogen in the large north-temperate lowland Lake Peipsi (Estonia/Russia). Hydrobiologia 599:31-39.

Kangur K, Möls T, Milius A, Laugaste R, 2003. Phytoplankton response to changed nutrient level in Lake Peipsi (Estonia) in 1992-2001. Hydrobiologia 506-509:265-272.

Kelderman P, Ang'weya RO, De Rozari P, Vijverberg T, 2012. Sediment characteristics and wind-induced sediment dy- 
namics in shallow Lake Markermeer, the Netherlands. Aquat. Sci. 74:301-313.

Kristensen P, Søndergaard M, Jeppesen E, 1992. Resuspension in shallow lake. Hydrobiologia 228:101-109.

Lagomarsino L, Pérez GL, Escaray R, Bustingorry J, Zagarese HE, 2011. Weather variables as drivers of seasonal phosphorus dynamics in a shallow hypertrophic lake (Laguna Chascomús, Argentina). Fund. Appl. Limnol. 178:191-201.

Laugaste R, Nõges P, Nõges T, Yastremskij VV, Milius A, Ott I, 2001. Algae, p. 31-49. In: E. Pihu, J. Haberman (eds.), Lake Peipsi: flora and fauna. Sulemees Publishers.

Loigu E, Leisk Ü, Iital A, Pachel K, 2008. [Pollution load and water quality of the Lake Peipsi basin], p. 179-199. In: J. Haberman, T. Timm, A. Raukas (eds.), [Peipsi]. [Book in Estonian]. Eesti Loodusfoto.

Nagid EJ, Canfield DE, Hoyer MV, 2001. Wind-induced increases in trophic state characteristics of a large $\left(27 \mathrm{~km}^{2}\right)$, shallow (1.5 m mean depth) Florida lake. Hydrobiologia 455:97-110.

Niemistö J, Tamminen P, Ekholm P, Horppila J, 2012. Sediment resuspension, rescue or downfall of a thermally stratified eutrophic lake. Hydrobiologia 686:267-276.

Nõges T, Järvet A, Kisand A, Laugaste R, Loigu E, Skakalski B, Nõges P, 2007. Reaction of large and shallow lakes Peipsi and Vorrtsjärv to the changes of nutrient loading. Hydrobiologia 584:253-264.

Nõges T, Nõges P, Laugaste R, 2003. Water level as the mediator between climate change and phytoplankton composition in a large shallow temperate lake. Hydrobiologia 506-509:257-263.

Pettersson K, George G, Nõges P, Nõges T, Blenckner T, 2010. The impact of the changing climate on the supply and recycling of phosphorus, p. 121-137. In: D.G. George (ed.), The impact of climate change on European lakes. Springer.

Pettersson K, Grust K, Weyhenmeyer G, Blenckner T, 2003. Seasonality of chlorophyll and nutrients in Lake Erken: effects of weather conditions. Hydrobiologia 506-509:75-81.

Rumyantsev VA, Kondrat'ev SA, Shmakova MV, Basova SL, Shilin BV, Zhuravkova ON, Savitskaya NV, 2005. [The external loading of Lake Peipsi and its response]. [Article in Russian]. Water Management of Russia 7:569-585.
SAS, 2008. SAS OnlineDoc, version 8. SAS Institute Inc. ed., Cary. Available from: http://v8doc.sas.com/ sashtml/

Søndergaard M, 2007. Nutrient dynamics in lakes - with emphasis on phosphorus sediment and lake restoration. $\mathrm{PhD}$ thesis. National Environmental Research Institute, University of Aarhus, Denmark: 276 pp.

Søndergaard M, Bjerring R, Jeppesen E, 2013. Persistent internal phosphorus loading during summer in shallow eutrophic lakes. Hydrobiologia 710:95-107.

Søndergaard M, Jensen JP, Jeppesen E, Møller PH, 2002. Seasonal dynamics in the concentrations and retention of phosphorus in shallow Danish lakes after reduced loading. Aquat. Ecosyst. Health 5:19-23.

Søndergaard M, Kristensen P, Jeppesen E, 1992. Phosphorus release from resuspended sediment in the shallow and windexposed Lake Arreso, Denmark. Hydrobiologia 228:91-99.

Spears BM, Carvalho L, Paterson DM, 2007. Phosphorus partitioning in a shallow lake: implications for water quality management. Water Environ. J. 21:47-53.

Spears BM, Carvalho L, Perkins R, Kirika A, Paterson DM, 2012. Long-term variation and regulation of internal phosphorus loading in Loch Leven. Hydrobiologia 681:23-33.

Spears BM, Carvalho L, Perkins R, Paterson DM, 2008. Effects of light on sediment nutrient flux and water column nutrient stoichiometry in a shallow lake. Water Res. 42:977-986.

Spears BM, Jones I, 2010. The long-term (1979-2005) effects of the North Atlantic Oscillation on wind-induced wave mixing in Loch Leven (Scotland). Hydrobiologia 646:49-59.

Starast H, Milius A, Möls T, Lindpere A, 2001. Hydrochemistry, p. 97-130. In: T. Nõges (ed.), Lake Peipsi. Meteorology, hydrology, hydrochemistry. Sulemees Publishers.

Stewart KM, Markello SJ, 1974. Seasonal variations in concentrations of nitrate and total phosphorus, and calculated nutrient loading for six lakes in western New York. Hydrobiologia 44:61-89.

Tammeorg O, Niemistö J, Möls T, Laugaste R, Panksep K, Kangur K, 2013. Wind-induced sediment resuspension as a potential factor sustaining eutrophication in large and shallow Lake Peipsi. Aquat. Sci. 75:559-570. 